NBER WORKING PAPER SERIES

TAX POLICIES FOR LOW-CARBON TECHNOLOGIES

\author{
Gilbert E. Metcalf \\ Working Paper 15054 \\ http://www.nber.org/papers/w15054 \\ NATIONAL BUREAU OF ECONOMIC RESEARCH \\ 1050 Massachusetts Avenue \\ Cambridge, MA 02138 \\ June 2009
}

I thank Frank Sammartino for helpful comments on a previous draft of this paper. The views expressed herein are those of the author(s) and do not necessarily reflect the views of the National Bureau of Economic Research.

NBER working papers are circulated for discussion and comment purposes. They have not been peerreviewed or been subject to the review by the NBER Board of Directors that accompanies official NBER publications.

(C) 2009 by Gilbert E. Metcalf. All rights reserved. Short sections of text, not to exceed two paragraphs, may be quoted without explicit permission provided that full credit, including $\odot$ notice, is given to the source. 
Tax Policies for Low-Carbon Technologies

Gilbert E. Metcalf

NBER Working Paper No. 15054

June 2009

JEL No. H23,Q48

\begin{abstract}
$\underline{\text { ABSTRACT }}$
The U.S. tax code provides a number of subsidies for low-carbon technologies. I discuss the difficulties of achieving key policy goals with subsidies as opposed to using taxes to raise the price of pollution-related activities. In particular, subsidies lower the cost of energy (on average) rather than raising it. Thus consumer demand responses work at cross purposes to the goal of reducing emissions (especially as average cost pricing is used for electricity). Second, it is difficult to achieve technology neutrality with subsidies - here defined as an equal subsidy cost per ton of $\mathrm{CO} 2$ avoided. Third, many subsidies are inframarginal. Finally, subsidies often suffer from unintended interactions with other policies.
\end{abstract}

I conclude with some observations on the use of price-based instruments. In particular I discuss how a carbon tax could be designed to achieve environmental goals of emission caps over a control period.

Gilbert E. Metcalf

Department of Economics

Tufts University

Medford, MA 02155

and NBER

gilbert.metcalf@tufts.edu 


\section{Tax Policies for Low-Carbon Technologies}

\section{Introduction}

The U.S. tax code provides a number of subsidies for low-carbon technologies. I discuss the difficulties of achieving key policy goals with subsidies as opposed to using taxes to raise the price of pollution-related activities. In particular, subsidies lower the cost of energy (on average) rather than raising it. Thus consumer demand responses work at cross purposes to the goal of reducing emissions (especially as average cost pricing is used for electricity). Second, it is difficult to achieve technology neutrality with subsidies - here defined as an equal subsidy cost per ton of $\mathrm{CO}_{2}$ avoided. Third, many subsidies are inframarginal. Finally, subsidies often suffer from unintended interactions with other policies.

The next section describes current tax policies to support low-carbon energy sources. In section III I discuss the issue of technology neutrality and some other problems with a subsidy-based approach to energy policy. The next section focuses on taxes versus production tax credits for wind generation, currently the largest recipient of tax subsidies in renewable electricity generation. I conclude with some observations on the use of price-based instruments. In particular I discuss how a carbon tax could be designed to achieve environmental goals of emission caps over a control period.

\section{Current Policies}

Current tax policy includes a variety of tax preferences for low-carbon technologies. I discuss the most important preferences in this section. While not especially costly in terms of foregone tax revenue, I will argue that these preferences have been important in shaping low-carbon energy investment over the past decade. 


\section{A. Electricity Generation}

A number of preferences in the tax code support the production of renewable electricity. ${ }^{1}$ Section 45 of the tax code provides production tax credits over the first ten years of electricity generation from wind, biomass, geothermal, municipal solid waste, qualified hydropower, and marine and hydrokinetic energy sources. The credit, originally enacted as part of the Energy Policy Act of 1992, provides a 2.1 cent per kWh credit for production in 2008 over ten years. ${ }^{2}$ The credit phases out as the average contract price of electricity exceeds 8 cents per kWh (in \$1992) - currently 11.8 cents in 2008. The reference price for 2007 announced by the IRS was 3.29 cents per kWh (IRB 2007-21).

Facilities eligible to receive the production tax credit (or the section 48 investment tax credit discussed below) are also eligible to write off these generation assets over a five year period. In the absence of this provision, the assets would be written off over a fifteen year period.

The production tax credit was most recently extended in the American Recovery and Reinvestment Act of 2009 (ARRA 2009). Wind projects must be put in place before Jan. 1, 2013; other projects in general before Jan. 1, 2014.

The Energy Policy Act of 2005 added a new production tax credit for new nuclear power generation (section 45J). Qualifying plants are eligible for a 1.8\$ per $\mathrm{kWh}$ production tax credit up to an annual limit of $\$ 125$ million per 1,000 megawatts of installed capacity. This limit will be binding for a nuclear power plant with a capacity

\footnotetext{
${ }^{1}$ For a more detailed description of energy related tax provisions, see Joint Committee on Taxation (2009).

2 This assumes facilities are placed in service after August 8, 2005. Certain facilities placed in service before this date only receive the credit over five years. The credit rate is 1.0 cent for open-loop biomass, small irrigation power, municipal solid waste, qualified hydropower, and marine and hydrokinetic power. These last two sources were not eligible for the credit for facilities put in place prior to August 8, 2005.
} 
factor of 80 percent or higher. There is an aggregate limit of 6,000 megawatts of capacity that is eligible for this credit. Qualifying facilities must be placed in service before the end of 2020. To date no new plants have been built though combined license applications for twenty-six units have been filed with the Nuclear Regulatory Commission. $^{3}$

Solar powered electricity is eligible for a 30 percent investment tax credit if put in place prior to the end of 2016 (the credit falls to 10 percent after that date). Certain other technologies are also eligible for this credit (residential solar projects, fuel cells and microturbine power plants, geothermal heat pump property (at a 10 percent rate), wind property no more than $100 \mathrm{~kW}$ of rated capacity, and certain combined heat and power systems (at 10 percent)). In addition, ARRA 2009 allowed certain section 45 qualified property to elect a 30 percent investment tax credit in lieu of the 2.1 cent per $\mathrm{kWh}$ production tax credit for property put in place through 2013 (2012 for wind). ARRA 2009 also provided for an option to elect a cash grant from the Department of Treasury in lieu of the production or investment tax credit for certain section 45 and 48 qualifying investments. The grant covers 30 percent of the cost of the qualified project and in effect extends the investment tax credit to firms that otherwise do not have sufficient tax appetite to utilize the credits. This addressed a concern, particularly important for the wind industry, that the financial crisis has dried up a major source of finance for the wind industry. ${ }^{4}$

\footnotetext{
${ }^{3}$ A list of the units is at http://www.nrc.gov/reactors/new-reactors/col.html. Website accessed on May 5, 2009.

4 See discussion in Chadbourne and Parke (January 2009). For an assessment of the relative merits of using the production versus the investment tax credit, see Bolinger et al. (2009).
} 
Other electricity related provisions include the exclusion for utility sponsored conservation measures from taxable income from utility customers and the credit for holding Clean Renewable Energy Bonds (CREBs). CREBs are designed to encourage the production of renewable electricity from developers that do not pay federal income

taxes (e.g. municipal governments and municipally owned power companies) and would otherwise not be eligible for production or investment tax credits. The Joint Committee on Taxation reports that over 900 projects have received allocations from CREB in 2006 and 2008 with solar projects accounting for nearly two-thirds of the projects and wind nearly one-quarter of the projects (see Table 1, Joint Committee on Taxation (2009)).

\section{B. Transportation Fuels}

Most of the tax provisions related to transport fuels are focused on reducing the reliance of the transport sector on petroleum. But some - arguably - also reduce carbon emissions.

The alternative motor vehicle credit (section 30B) provides investment tax credits for certain fuel cell vehicles, hybrids, plug-in hybrids, and advanced lean burn technology vehicles. Qualified fuel cell vehicles are eligible for base credits ranging from $\$ 8,000$ to $\$ 40,000$ with additional credits based on fuel economy relative to base fuel economy. Credits for hybrid automobiles and light trucks combine a fuel economy and a conservation credit with the maximum possible credit equally $\$ 3,400$ based on vehicle characteristics. The credit phases out once the manufacturer's sales of hybrid vehicles reaches 60,000. A similar phase out exists for the advanced lean burn technology vehicles. Plug in hybrids become eligible for a base credit of \$2,500 for the years 2009 
with a supplemental credit of $\$ 417$ per $\mathrm{kWh}$ of battery capacity in excess of four kWhs. The maximum credit ranges from $\$ 10,000$ to $\$ 15,000$ depending on vehicle weight.

The Volumetric Ethanol Excise Tax Credit (VEETC) currently provides a 45 cent per gallon of ethanol exemption from the motor fuels excise tax. For ethanol blended at a 10 percent rate, this reduces the fuel tax by 4.5 cents per gallon of blended fuel. Whether corn-based ethanol should be viewed as a low-carbon technology is a matter of some

controversy. ${ }^{5}$ In addition to VEETC, various other credits are provided including a $\$ 1.00$ per gallon credit for biodiesel and a \$.50 per gallon for alternative fuels and alternative fuel mixtures. I discuss this latter credit further below.

\section{Efficiency and Other}

A variety of energy efficiency investment credits exist for nonbusiness (residential) property. A credit equal to 30 percent of the cost of qualified investments (windows, doors, insulation, burners, etc.) up to $\$ 1,500$ is eligible for investments through 2010. ${ }^{6}$ Manufacturer credits for energy efficient new homes range from $\$ 1,000$ to $\$ 2,000$ depending on the efficiency improvements and extend through this year. Manufacturer credits are provided for appliances meeting higher efficiency standards through 2010. Manufacturers are limited to maximum claims of $\$ 75$ million in aggregate with the exception of the credit for highest efficiency clothes washers and refrigerators.

\section{Summary of Low-Carbon Energy Tax Benefits}

Table 1 provides an estimate of the tax expenditures related to low-carbon fuels from the President's latest budget submission.

\footnotetext{
5 See, for example, Searchinger et al. (2008) and responses to this article published subsequently in Science.

${ }^{6}$ This was raised from $\$ 500$ to $\$ 1,500$ in ARRA 2009.
} 


\begin{tabular}{|l|r|r|}
\hline \multicolumn{3}{|c|}{ Table 1. Low-Carbon Energy Tax Expenditures } \\
\hline \multicolumn{1}{|c|}{ Item } & FY09 & \multicolumn{1}{|c|}{ FY09-13 } \\
\hline New Technology Credit (Sec. 45 and 48) & 1,000 & 5,010 \\
\hline Alcohol Fuels and VEETC & 5,190 & 12,930 \\
\hline Biodiesel & 30 & 80 \\
\hline Clean-Fuel Burning Vehicles & 130 & -50 \\
\hline Exclusion of Utility Conservation Subsidies & 120 & 560 \\
\hline CREBs & 70 & 350 \\
\hline New Home Construction Efficiency Credit & 20 & 30 \\
\hline Existing Home Efficiency Investment Credit & - & - \\
\hline Energy Efficient Appliance Credit & - & 10 \\
\hline Residential Solar/Fuel Cell Credit & 10 & 10 \\
\hline $\begin{array}{l}\text { Business Credit for Fuel Cells and Microturbine } \\
\text { Power }\end{array}$ & 50 & - \\
\hline $\begin{array}{l}\text { Source: Office of Management and Budget (2009). Certain benefits are not counted as } \\
\text { tax expenditures, for example the five year write-off of investments eligible for the new } \\
\text { technology credits. }\end{array}$ \\
\hline
\end{tabular}

The tax expenditures associated with low-carbon energy are not that large in the grand scheme but they are not insignificant. The largest by far is VEETC and other alcohol fuel related credits totaling nearly $\$ 13$ billion over five years. The New Technology Credits (production and investment tax credits) are the second largest category accounting for over $\$ 5$ billion over five years. ${ }^{7}$ ARRA 2009 will likely drive up the revenue costs of some of these measures. Joint Committee on Taxation estimates that changes in the new technology tax credits will have a five year budget impact (FY20092013) of over $\$ 3$ billion. The extension and more generous treatment of residential home efficiency improvements will add another $\$ 2$ billion in revenue costs over five years. The five year revenue impact for all the energy provisions in ARRA 2009 amount to \$6.2 billion. These legislative changes are all directed at low or zero carbon technologies.

\footnotetext{
7 Certain non-renewable fuels are eligible for the New Production Tax Credit. Analysis by Energy Information Administration (2008) suggests that nearly all of the credit in FY 2007 went to wind.
} 
I turn next to an analysis of these subsidies and relate them to larger policy goals.

In particular, I focus on the potential for using tax subsidies to achieve technology neutrality among energy sources.

\section{Technology Neutrality in Carbon Policy}

Economic theory provides clear prescriptions for situations where interventions through the tax code can improve social welfare. ${ }^{8}$ Externalities provide the most relevant rationale for the energy sector. If the production or consumption of energy has as a byproduct the creation of an externality (e.g. pollution) then social welfare can be improved through government intervention. One way to do this is by taxing the externality. Thus a tax on the sulfur content of fossil fuels, for example, would be an efficient response to acid rain damages arising from fossil fuel consumption for electricity generation. This is an example of a Pigouvian tax. ${ }^{9}$ It "internalizes the externality" by forcing firms to take into account the social costs of pollution by raising their private costs by the amount of the social damages that are generated by the pollutant. This approach implicitly makes clear that pollution generating activities have social benefits as well as costs. Optimal policy must balance those costs against the benefits; the tax is an efficient means of effecting that balance.

Rather than taxing activities that create negative externalities, we can provide subsidies to activities that are substitutes for externality generating activities. Put simply, if fuel $\mathrm{X}$ generates pollution damages while fuel $\mathrm{Y}$ does not, we can raise the price of fuel

\footnotetext{
8 This section draws on testimony I provided to the Senate Finance Committee in a hearing focusing on Technology Neutrality in Energy Tax: Issues and Options held on April 23, 2009.

9 Named for the economist Arthur C. Pigou, an early proponent of this policy instrument in Pigou (1932). A comparable approach - and the one taken to address acid rain - is to create a cap-and-trade system for $\mathrm{SO}_{2}$. Either approach puts a price on emissions of $\mathrm{SO}_{2}$ and provides the appropriate price signal to electric utilities to reduce emissions.
} 
$\mathrm{X}$ relative to fuel $\mathrm{Y}$ to reflect the social damages from burning fuel $\mathrm{X}$ or we can reduce the price of fuel Y. Either approach encourages firms to use less of fuel $\mathrm{X}$ and more of fuel Y. This is the essential approach taken through federal energy tax policy. In large measure, we subsidize energy activities that we would like to encourage rather than tax activities that we would like to discourage.

What are the externalities that are of significant concern that drive federal tax policy towards energy? Two concerns dominate the agenda. First is the concern with global climate change arising from increasing concentrations of greenhouse gases in the atmosphere. Fossil fuel combustion in the United States was responsible for eighty percent of domestic greenhouse gas emissions in $2007 .^{10}$ Any policy to reduce U.S. greenhouse gas emissions must have as a key element incentives to shift from fossil to renewable fuels consumption.

A second concern is our heavy reliance on petroleum products and the dominance of this fuel in the transportation sector. In 2007 seventy percent of petroleum products were used by the transportation sector. Conversely, petroleum accounted for over 95 percent of the fuel used in this sector. Our reliance on petroleum makes us vulnerable to economic dislocations from sharply rising oil prices or supply disruptions.

Energy production and consumption are associated with negative externalities in addition to climate change and oil dependence. I do not focus on those here because many of these negative externalities are currently addressed through regulatory means. For example, the Acid Rain Program run by the Environmental Protection Agency has been a highly cost-effective response to the damages from releasing sulfur dioxide in fossil fuel electric generation units. Moreover the current set of energy subsidies is

10 See Environmental Protection Agency (2009). 
arguably focused to a large extent on reducing greenhouse gas emissions and reducing our consumption of oil.

An efficient energy policy should not favor one energy source over another after taking into account any positive or negative externalities associated with its production or consumption. This is the concept of technology neutrality. If our focus is on global warming due to anthropogenic greenhouse gas emissions, a technology neutral policy would raise the price of emissions per unit of carbon dioxide equivalent $\left(\mathrm{CO}_{2} \mathrm{e}\right)$ by the same amount. A comprehensive carbon tax or cap and trade system does this.

It is trickier - as we shall see - to achieve technology neutrality when subsidies are used instead of taxes. For the purposes of this analysis, I will measure technology neutrality in terms of the cost of achieving a given amount of carbon dioxide reductions as a result of the subsidy. The benefit of this approach is that it calibrates the measure of the tax code's impact to the policy goals we care about (reducing greenhouse gas emissions). If the tax subsidy per ton of avoided greenhouse gas emissions from technology $\mathrm{X}$ is twice that of reducing emissions from technology $\mathrm{Y}$ then we can say that our tax policy favors technology $\mathrm{X}$ over $\mathrm{Y}$ on this dimension.

This definition of technology neutrality is not the same as efficiency in abatement of pollution. The latter requires that the marginal cost of pollution abatement be equalized across energy sources. Unless subsidies are designed in terms of a payment per unit of pollution reduced it is difficult if not impossible to achieve economic efficiency across fuel types. Moreover, as I discuss below, even if subsidies are constructed in this fashion, it is difficult to disentangle true emission reductions from reductions that would have taken place in the absence of the tax subsidy. 
Using subsidies within the tax system to achieve energy policy goals has been a time honored custom throughout the history of the U.S. income tax. It is important, however, to recognize the limitations of subsidies in achieving efficient outcomes. First note that a subsidy based approach achieves the important goal of adjusting relative prices of polluting and non-polluting energy sources in the right direction. If fuel source $\mathrm{X}$ causes pollution that is equal to 10 percent of its cost then we can provide the right incentive to fuel users choosing between fuel sources $\mathrm{X}$ and $\mathrm{Y}$ by raising the price of $\mathrm{X}$ by 10 percent or by lowering the cost of fuel source $\mathrm{Y}$ by $1 /(1.10)$ or 9.1 percent. Either way the relative cost of fuel source $\mathrm{X}$ to $\mathrm{Y}$ is now ten percent higher than it was prior to the implementation of new energy policy. Either a tax or a subsidy can be effective on the margin of choosing among fuel sources where some sources cause pollution.

This creates a problem, however, on a different margin. Efficiency requires that consumers make decisions taking into account the full cost of using commodities including the pollution costs associated with using energy. Raising the cost of the polluting fuel source $\mathrm{X}$ raises the overall cost of energy use and encourages a reduction in energy consumption. More precisely, consumers shift away from consuming energy to consuming other goods. This substitution is driven by the higher overall cost of energy. Subsidizing the clean substitute undermines this consumer substitution effect as it leads to a lower cost of energy overall. Consumers do not reduce energy consumption as much as they would under a cost-raising policy.

Second, subsidies that appear to be technologically neutral may not be neutral at all in the sense of equalizing the subsidy cost per unit of activity that Congress is trying to discourage. Consider the tax credit for hybrid vehicles put in place in the Energy 
Policy Act of 2005. The credit ranges from zero to $\$ 3,000$ per vehicle depending on whether the vehicle meets the specific hybrid criteria and on how many vehicles have been sold. The credit phases out as the vehicle hits certain sales targets over time. Table 2 shows the subsidy cost per gallon of gasoline saved through this credit for a number of vehicles. The tax credit is for model 2009 vehicles. I measure the savings relative to a vehicle that gets 20 miles per gallon assuming the vehicle is driven the average number of miles currently driven by private vehicles in the United States.

\begin{tabular}{|c|c|c|c|c|c|}
\hline \multicolumn{6}{|c|}{$\begin{array}{l}\text { Table 2. Hybrid Vehicle Tax Credit } \\
\text { Model } 2009 \text { Values }\end{array}$} \\
\hline Vehicle & MPG & $\begin{array}{c}\text { Hybrid } \\
\text { Vehicle Tax } \\
\text { Credit }\end{array}$ & $\begin{array}{l}\text { Annualized } \\
\text { Value of } \\
\text { Credit }\end{array}$ & $\begin{array}{c}\text { Annual } \\
\text { Gasoline } \\
\text { Savings } \\
\text { (Gallons) }\end{array}$ & $\begin{array}{c}\text { Tax Credit } \\
\text { per Gallon o } \\
\text { Gasoline } \\
\text { Saved } \\
\end{array}$ \\
\hline $\begin{array}{c}\text { Chrysler Aspen } \\
\text { Hybrid }\end{array}$ & 21 & $\$ 2,200$ & $\$ 347$ & 30 & $\$ 11.68$ \\
\hline $\begin{array}{c}\text { Ford Escape } \\
\text { Hybrid (2WD) }\end{array}$ & 32 & $\$ 3,000$ & $\$ 474$ & 234 & $\$ 2.02$ \\
\hline $\begin{array}{l}\text { Mazda Tribute } \\
\text { Hybrid (2WD) }\end{array}$ & 32 & $\$ 3,000$ & $\$ 474$ & 234 & $\$ 2.02$ \\
\hline $\begin{array}{l}\text { Nissan Altima } \\
\text { Hybrid }\end{array}$ & 34 & $\$ 2,350$ & $\$ 371$ & 257 & $\$ 1.44$ \\
\hline Toyota Corolla & 31 & $\$ 0$ & $\$ 0$ & 222 & $\$ 0$ \\
\hline Toyota Prius & 46 & $\$ 0$ & $\$ 0$ & 353 & $\$ 0$ \\
\hline
\end{tabular}

The table illustrates several points. First, the tax credit per gallon of gasoline saved varies from zero to over $\$ 11$ per gallon. Second, certain hybrid vehicles that get high mileage are excluded from the credit because they have been successful in the market place. Third, certain high mileage vehicles are excluded from the subsidy because they do not use specified technology. Note that the Corolla gets nearly the same 
mileage as the Tribute Hybrid. This is the most egregious violation of technology neutrality. The tax credit provides no incentive to tinker with the internal combustion engine to achieve increases in vehicle efficiency despite the many opportunities that exist to make the internal combustion engine more efficient. Our tax policy should provide the same incentives to improve mileage regardless of the technology put in place. Only in this way is true technology neutrality achieved. ${ }^{11}$

The hybrid vehicle tax credit is a clear example of inefficient allocation of resources across fuel saving capital investments. It is not the only example, however. Inefficient allocations can occur even when policies appear to be technology neutral. Consider the production tax credit for electricity generated from renewable sources. Currently the tax credit is worth $2.1 \$$ per kWh for electricity over the first ten years of the plant's life. ${ }^{12}$ This policy appears to be technology neutral (assuming all renewable technologies are made eligible for the credit). Renewable in this context means carbonfree. But consider Table 3 which compares the production tax credit for wind with that for geothermal energy.

\begin{tabular}{|l|c|c|c|}
\hline \multicolumn{4}{|c|}{ Table 3. Production Tax Credit } \\
\hline Renewable Source & PTC & $\begin{array}{c}\text { Capacity } \\
\text { Factor }\end{array}$ & $\begin{array}{c}\text { Subsidy per } \\
\text { ton CO } \mathbf{C O}_{2}\end{array}$ \\
\hline Geothermal & $\$ 0.021$ & $73 \%$ & $\$ 7.74$ \\
\hline Wind & $\$ 0.021$ & $27 \%$ & $\$ 12.28$ \\
\hline $\begin{array}{l}\text { Source: Author's calculations. Capacity factor based on electricity generation in } \\
\text { 2006. } \mathrm{CO}_{2} \text { emissions avoided assume geothermal replaces coal fired base load } \\
\text { capacity while wind replaces natural gas shoulder or peaking capacity. Coal and } \\
\text { natural gas emissions based on EIA estimates. }\end{array}$ \\
\hline
\end{tabular}

11 Others have noted the inconsistent treatment of different vehicles and provided calculations similar to those in Table 2 including Sullivan (2009) and Joint Committee on Taxation (2009).

${ }_{12}$ As noted above, certain sources (e.g. municipal solid waste and open loop biomass) are eligible for a tax credit at half this rate. 
The subsidy per ton of carbon dioxide avoided critically depends on which power source is displaced by the new renewable capacity addition. Geothermal power, for example, has a capacity factor of over 70 percent - meaning that it is producing power on average for 70 percent of the year - while wind's capacity factor is less than 30 percent. $^{13}$ Geothermal power is more likely to displace base load coal units than natural gas while the opposite is true for wind. Under the assumption that geothermal displaces coal and wind displaces natural gas, the subsidy for the former is $\$ 7.74$ per ton of carbon dioxide avoided while the subsidy for wind is $\$ 12.28$ per ton. The difference arises because coal emits on average one ton of $\mathrm{CO}_{2}$ per MWh of electricity generation while natural gas emits on average roughly two-thirds of a ton of $\mathrm{CO}_{2}$ per MWh.

The point here is not whether geothermal displaces coal and wind natural gas (or even whether the displaced fuel is constant over time). Rather the point is that a technology neutral policy focused on reducing greenhouse gas emissions should favor technologies that are more likely to displace coal than natural gas. The current new technology credits do not take this into account.

A related point is the lack of transparency in a subsidy-based policy. It is difficult to identify the cost per ton of $\mathrm{CO}_{2}$ displaced with either of the policies discussed above. The current proposal for a "cash for clunkers" program also illustrates this point. A recent paper by Davis and Kahn (2008) suggests that the cars most likely to be candidates for a cash for clunkers program would have emitted about 47 tons of carbon dioxide over their remaining life had they not been scrapped. At a cost of $\$ 2,500$ the cash for clunkers

\footnotetext{
${ }^{13}$ The capacity factor for wind depends importantly on location and turbine design. Capacity factors as high as 40 percent are not out of the question. But even at higher capacity factors the point of this example is unaffected. The capacity factor cited in this table is the average over all existing and operating wind facilities in the United States.
} 
program costs over $\$ 50$ per ton of $\mathrm{CO}_{2}$ saved. Once you factor in the possibility that very old cars that have been already taken off the road but not scrapped are brought in for the payment, the cost per ton rises dramatically. The current House cash for clunkers proposal will provide vouchers for $\$ 3,500$ or $\$ 4,500$ depending on the mileage difference between a traded in vehicle and its replacement (Herszenhorn (2009)). The cost of saving a ton of carbon dioxide gets obscured in the details of the program

In summary, the current set of subsidies to encourage reductions in petroleum consumption and greenhouse gas emissions have two drawbacks. First, they generate a distortion on the margin between energy consumption and consumption of other nonenergy commodities. Second, they generate distortions among the externality-reducing technologies in a way that raises the cost of achieving our policy goals while doing so in a fairly opaque way.

In addition to the pricing issues discussed above, the current set of energy tax initiatives have other issues that could fruitfully be addressed by lawmakers. The first issue is that of stability and clarity in the policy. The historic pattern of two-year authorization cycles for production tax credits has created great uncertainty in the wind industry and led to boom and bust cycles that raise the cost of renewable energy investment. Greater certainty over the production tax credit would smooth out investment and reduce bottlenecks in turbine manufacture that delay projects and raise costs. A related issue is the ability to use tax benefits. One casualty of the current financial crisis is the reduced tax appetite of firms that historically have invested in wind and other renewable projects. The provision of the cash rebate option in ARRA 2009 addresses this concern. 
A second key design issue is that of additionality. Does the policy lead to incremental reductions in pollution or simply subsidies for emission reducing activities that would have occurred in the absence of the policy? A good example of this is the $\$ .50$ per gallon alternative fuels mixture credit. This credit is intended to encourage the addition of biodiesel and other biomass based fuels to petroleum to reduce petroleum use. Recently it has emerged that many paper firms are taking the credit for mixing diesel fuel with black liquor, a biomass by-product of paper making that historically has been used by the industry as a fuel source for their boilers. Controversy has arisen over whether paper firms are adding diesel fuel to black liquor purely for the purpose of claiming the tax credit biodiesel mixture tax credit. ${ }^{14}$ This is troubling on two levels. First, it may be highly inefficient if credits are being provided for inframarginal activities. This is a common problem with any subsidy. We want to provide the incentive to firms that would not have undertaken the desirable activity in the absence of the subsidy. But we don't want to provide the subsidy to firms that would have undertaken the activity regardless of the subsidy. But the example from the paper industry is troubling beyond the inframarginal nature of the subsidy. If the tax credit is raising the demand for diesel fuel in order to make the biofuel eligible for the credit, then it is having the perverse effect of raising rather than lowering demand for petroleum products. ${ }^{15}$

A third important design issue is the interaction between tax policy and other policies. A simple example here is the interaction of the hybrid vehicle tax credit and the Corporate Average Fuel Economy (CAFE) standards. Allowing tax credits for hybrids

\footnotetext{
14 See Mouawad and Krauss (2009).

15 The perverse impact of policy is not limited to the biodiesel mixing tax credit. Research by Holland, Hughes and Knittel (2009) suggest that low carbon fuel standards may have the perverse effect of increasing net carbon emissions.
} 
encourages the production and purchase of high mileage vehicles. But CAFE sets minimum fleet mileage standards for automakers. Producing more hybrid vehicles relaxes the CAFE mileage constraint for automakers and allows them to sell more low mileage vehicles. ${ }^{16}$ One possible policy response to this would be to exclude credit receiving hybrids from the fleet for purposes of meeting CAFE standards. Alternatively one could eliminate the credit and simply let CAFE be the driving incentive for hybrid production.

Two other examples illustrate the unintended consequences of policy interaction. First, state renewable portfolio standards like California's 20 percent RPS program by 2010 are driving up the cost of the federal production tax credit. The most recent Administration budget shows tax expenditures from the new technology tax credit rising from $\$ 800$ million in FY2008 to $\$ 1000$ million in FY2009 to \$1030 in FY2010. Part of this increase is driven by requirements for renewable electricity at the state level.

Second, the ethanol tax credit of $\$ .45$ per gallon of ethanol is inframarginal to the extent that other regulations mandate the use of ethanol in gasoline stocks. In Metcalf (2008) I argue that ethanol mandates in the Energy Policy Act of 2005 along with other pollution-required demands for ethanol in reformulated gasoline make the ethanol tax credit largely inframarginal. With generous assumptions about carbon displacement from ethanol relative to gasoline, I calculate that the subsidy through the ethanol tax credit exceeds \$1,700 per ton of $\mathrm{CO}_{2}$ displaced in 2005 and 2006.

\footnotetext{
${ }^{16}$ Alternatively and equivalently, it leads to the substitution of hybrid vehicles for other high mileage vehicles that in the absence of hybrids the automakers market primarily to meet CAFE fleet standards.
} 


\section{Taxes versus Subsidies}

Most if not all of the problems identified in the previous section disappear if we replace the current system of tax subsidies for carbon free technologies with taxes on fossil fuels. I begin by assessing the "carbon tax equivalent" for production tax credits using a levelized cost framework. ${ }^{17}$ The levelized cost of an electricity generating project is the constant amount of revenue per kilowatt-hour required to cover all the costs of an investment project (including returns to equity investors).

I compare the levelized cost of an advanced combustion turbine for gas with a wind project under the assumption that at the margin wind and natural gas are competitive fuel sources. If investors are choosing between these two technologies on the basis of levelized cost, I consider what tax incentives are required to make wind competitive with natural gas. A number of factors affect the relative cost of wind and natural gas powered generators. I focus on two in particular in this paper: the cost of natural gas and the relative capital cost escalation for wind to gas.

Figure 1 shows how natural gas prices paid by electric utilities have fluctuated over the past seven years. They hit a (nominal) peak in June 2008 but since then have fallen by nearly fifty percent. The decline in gas prices makes wind that much less competitive against natural gas generation.

17 See Metcalf (2007) for a discussion of this methodology. 


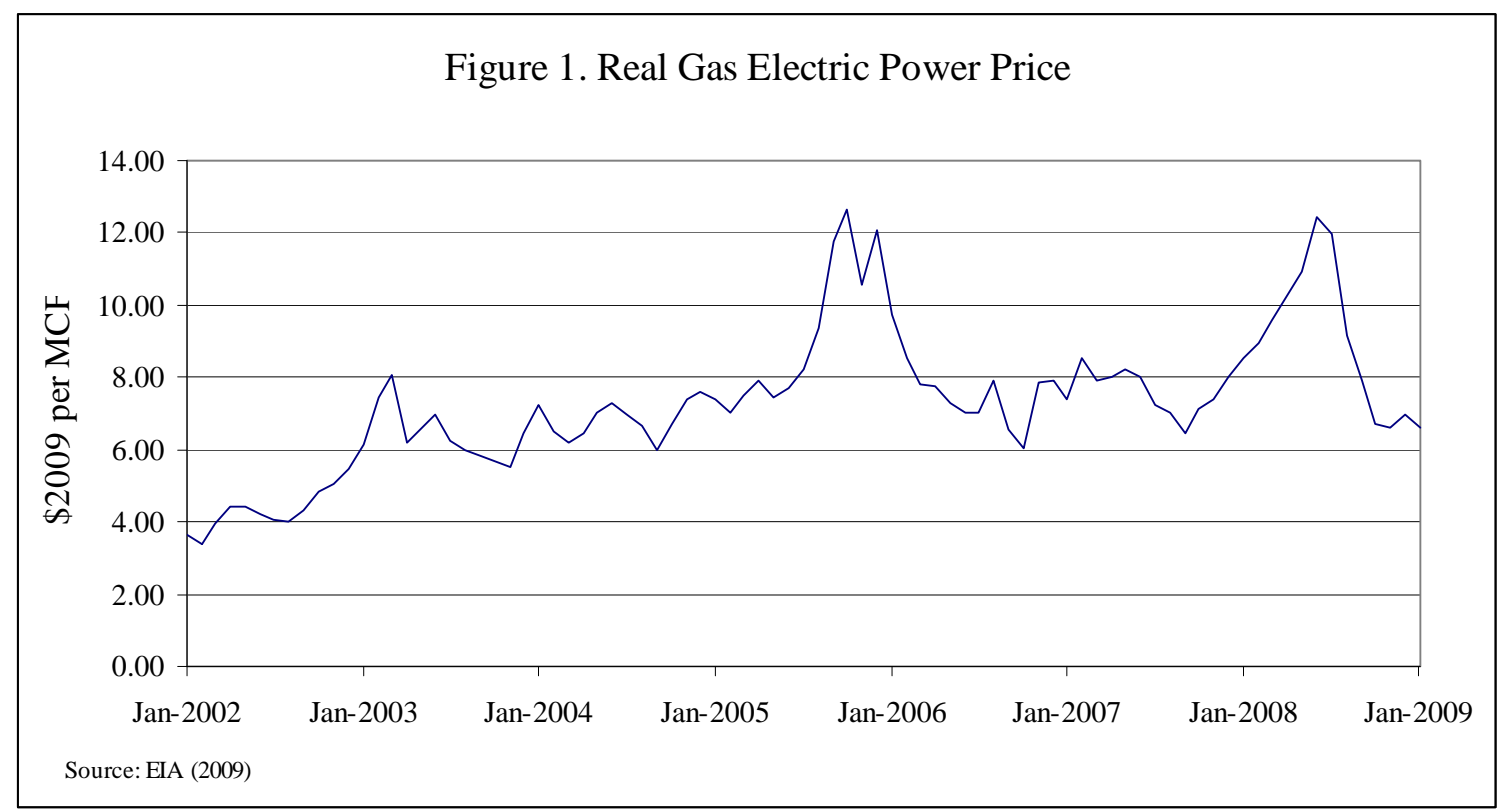

The other factor that influences the relative cost of wind and natural gas is capital costs. Based on data from EIA's Annual Energy Outlook, the capital costs of wind are nearly three times that of gas. Wiser and Bolinger (2008) document rising construction costs for recent wind projects with increasing turbine costs playing a significant role. It may be that future cost increases are comparable to those of gas (or perhaps even less) but wind is disadvantaged to the extent that its capital costs rise at a more rapid rate than that of its competitors.

Based on the technology and economic assumptions detailed in the appendix, the levelized cost of a wind project is 2 percent lower than that for natural gas fired electricity in the absence of the production tax credit. ${ }^{18}$ This suggests that at current prices the production tax credit for new wind projects is inframarginal.

Table 4 reports the required production tax credit to ensure that the levelized cost of wind is no higher than that of natural gas for different gas price and wind capital cost

18 The levelized cost of wind is 8 percent higher if no production tax credit is allowed and the asset is written off over 15 years instead of 5 . 
assumptions. The capital cost escalation factor is the amount by which the wind overnight cost is assumed to increase over its base value assumed in the appendix.

\begin{tabular}{|c|c|c|c|c|c|}
\hline \multicolumn{5}{|c|}{ Table 4. } & Cost Equalizing Production Tax Credit \\
\hline \multicolumn{2}{|c|}{} & \multicolumn{4}{|c|}{ Capital Cost Escalation Factor } \\
\cline { 3 - 6 } \multicolumn{2}{|c|}{} & 1.00 & 1.10 & 1.25 & 1.50 \\
\hline \multirow{3}{*}{ Fuel Cost } & 5 & 0.017 & 0.022 & 0.030 & 0.044 \\
\cline { 2 - 6 } (\$/MCF) & 6 & 0.008 & 0.013 & 0.021 & 0.035 \\
\cline { 2 - 6 } & 7 & - & 0.004 & 0.012 & 0.026 \\
\cline { 2 - 6 } & 8 & - & - & 0.003 & 0.017 \\
\hline
\end{tabular}

Source: Author's calculations. Entries are production tax credit in dollars per $\mathrm{kWh}$ that reduce levelized cost of wind to that of natural gas.

Based on the economic and technology assumptions contained in the appendix,

Table 4 shows that the current production tax credit is sufficient to make wind costcompetitive with natural gas at a fuel cost of \$6 per MCF and a cost escalation for wind capital costs of 25 percent. Given the current capital costs assumed in EIA's Annual Energy Outlook, natural gas prices would have to fall below $\$ 5$ per MCF before a production tax credit of 2.1 cents per $\mathrm{kWh}$ would be required. In other words, it appears that the production tax credit is an inframarginal subsidy under current economic conditions.

Given the problems with using subsidies to support low-carbon energy production, a natural question is what carbon tax would be required to obtain the same result as we get in Table 4 with production tax credits. Table 5 presents that information.

\begin{tabular}{|c|c|c|c|c|c|}
\hline \multicolumn{6}{|c|}{ Table 5. Cost Equalizing Carbon Tax } \\
\hline & & \multicolumn{4}{|c|}{ Capital Cost Escalation Factor } \\
\hline & & 1.00 & 1.10 & 1.25 & 1.50 \\
\hline \multirow{4}{*}{$\begin{array}{l}\text { Fuel Cost } \\
\text { (\$/MCF) }\end{array}$} & 5 & 35 & 47 & 64 & 94 \\
\hline & 6 & 16 & 28 & 45 & 74 \\
\hline & 7 & - & 9 & 26 & 55 \\
\hline & 8 & - & - & 7 & 36 \\
\hline
\end{tabular}


One striking fact about Table 5 in comparison to Table 4 is the magnitude of the carbon tax required to be equalize the levelized costs of both technologies. Moreover, Table 5 indicates that a carbon tax of $\$ 45$ per metric ton of $\mathrm{CO}_{2}$ is comparable to the current production tax credit of $\$ 0.021$ per $\mathrm{kWh}$. The high carbon price required to be equivalent in impact to the production tax credit simply reflects the fact that wind in this model is replacing a relatively low-carbon fuel (relative to coal). A carbon tax of only \$25 is comparable to a $\$ .021$ per $\mathrm{kWh}$ production tax credit for wind if wind is substituting for coal.

In the previous section I argued that a technology neutral subsidy for low-carbon energy would take into account the carbon content of the fuel that it displaced. If the purpose of a production tax credit is simply to make wind cost competitive with fossil fuel power sources, it should take into account the profitability of the wind project. The higher the capacity factor of the project, ceteris paribus, the more profitable the project is. Table 6 reports capacity factors for wind projects installed in 2006 averaged across regions of the country. If our focus is on cost competitiveness Table 6 suggests that the production tax credit should be highest in New England and lowest in the Midwest of the United States. I'm not suggesting that the United States should implement this policy but rather note this to illustrate the confused policy objectives behind this particular energy tax subsidy. 


\begin{tabular}{|c|c|}
\hline \multicolumn{2}{|c|}{$\begin{array}{c}\text { Table 6. Regional Wind } \\
\text { Capacity Factors }\end{array}$} \\
\hline Region & $\begin{array}{l}\text { Capacity } \\
\text { Factor }\end{array}$ \\
\hline Midwest & $40.8 \%$ \\
\hline Texas & $30.4 \%$ \\
\hline California & $36.9 \%$ \\
\hline Northwest & $31.3 \%$ \\
\hline Mountain & $34.7 \%$ \\
\hline East & $29.4 \%$ \\
\hline Hawaii & $45.0 \%$ \\
\hline New England & $22.1 \%$ \\
\hline
\end{tabular}

What would a price based approach look like? The two competing options are cap-and-trade programs and carbon taxes. Political momentum favors the former approach while ease of administration and efficiency favors the latter. The interested reader is referred to Metcalf and Weisbach (forthcoming) for details on how a carbon tax could be implemented. Many of the design considerations also apply to cap-and-trade programs.

Here I simply wish to note one argument against carbon taxes often raised by environmentalists: that a cap-and-trade program provides certainty in the environmental outcome while the carbon tax does not. ${ }^{19}$ In Metcalf (2009a) I describe a carbon tax that meets long-term emission targets while providing the price certainty advantages of a tax. The Responsive Emissions Autonomous Carbon Tax (REACT) sets an initial tax rate at the beginning of the control period (say, 2012) and increases the tax at a standard rate of four percent plus inflation. In benchmark years (perhaps every five years) cumulative emissions since the beginning of the control period are compared to a target cumulative

${ }^{19}$ See, for example, the posting by Gernot Wagner and Nathaniel Keohane, "The case for cap-and-trade: There's certainty in the environmental outcome" posted on the Bulletin of the Atomic Scientists Roundtable on Carbon tax versus cap and trade at http://www.thebulletin.org/web-edition/roundtables/carbon-tax-vscap-and-trade accessed on May 5, 2009. 
emissions goal for that year. If actual cumulative emissions exceed the target in the benchmark year, the tax is increased at a "catch-up" rate of ten percent plus inflation until the next benchmark year. If cumulative emissions in that year are below the target the rate drops back to the standard rate. If not, it stays at the higher catch-up rate. ${ }^{20}$

This policy approach ensures that long-run targets are met while price stability is achieved in the short run. Given the ability to predict emissions in the short run and the transparent nature of the tax, firms would be able to predict with considerable certainty what the growth rate of the tax will be in the near term thereby providing greater clarity for their planning purposes. The REACT approach addresses the objection that a carbon tax does not ensure a hard cap on greenhouse gas emissions over the control period. An overall cap can be maintained while insulating consumers and businesses from short-run fluctuations in carbon prices that add volatility to energy prices and undermine support for climate change legislation. It does this with a transparent mechanism for adjusting the price of emissions over the control period.

\section{Conclusion}

The current tax code relies on a large number of subsidies through accelerated depreciation, tax exemptions, production credits and investment credits to support lowcarbon technologies. This approach is flawed on a number of levels. First, it lowers the price of consuming energy relative to other goods. Second, the subsidies are not cost effective in that they do not equalize the subsidy cost per ton of $\mathrm{CO}_{2}$ that is not emitted. Third, to the extent that the subsidy is inframarginal it raises the cost to the federal government of achieving its policy objectives. Finally, subsidies interact in unexpected

${ }^{20}$ This approach is similar in spirit to the managed price approach described in Elmendorf (2009). 
ways with other state and federal policies in ways that either undermine the effectiveness of the subsidy or drive up the cost of the program.

An approach that improves in the area of economic efficiency is a market-based approach such as a cap-and-trade system or a carbon tax. The Responsive Emissions Autonomous Carbon Tax is one approach to implementing a carbon tax that addresses the concern that a tax-based approach does not guarantee that emission goals are achieved.

If the United States does implement a carbon tax, an important question will be whether it preserves or eliminates the various subsidies to low-carbon fuels that are in the tax code. It is difficult to make a case for preserving them if carbon pricing comes into effect. 


\section{Appendix: Levelized Cost Analysis}

The levelized cost of a project is calculated in two steps. First, we compute the required annual revenue $(R)$ that makes the net present value of a project equal to zero taking into account all costs and taxes:

$$
\sum_{t=k+1}^{T+k} \frac{R}{(1+r)^{t}}=\sum_{t=1}^{T+k} \frac{C_{t}-\operatorname{Tax}_{t}}{(1+r)^{t}}
$$

where $T$ is the number of years that the plant operates, $k$ is the number of years that it takes to construct the plant, $C_{t}$ is the annual cash outlays of the project and $\operatorname{Tax}_{t}$ is the annual tax (net of any tax benefits). All values are in real terms and $r$ is the real discount rate used by the firm. ${ }^{21}$

In step 2, the annual required revenue is converted to a cost per $\mathrm{kWh}(c)$ as

\section{follows:}

$$
c=\frac{R}{365 \cdot 24 \cdot \phi}
$$

where $\phi$ is the capacity factor for the project (the percentage of time the project is online through the year). Equation 2 simply divides the annual revenue by the number of hours the project operates in the year. Since all project costs are reported per $\mathrm{kW}$ of capacity, this yields the cost per kWh for the project.

Table A1 presents the economic assumptions used in the analysis.

\footnotetext{
${ }^{21}$ A constant discount rate is used over the project's life. I calculate the net present value as if the project were all-equity financed but include the tax benefits of debt (deductions for interest paid). This allows me to use a constant discount rate despite the changing debt-equity ratio of the project as debt is paid down. See Brealey and Myers (1981) for a fuller treatment of project discounting.
} 


\begin{tabular}{|l|c|}
\hline \multicolumn{2}{|c|}{ Table A1. Economic Assumptions for Analysis } \\
\hline Real Required Return To Equity & $10 \%$ \\
\hline Inflation Rate & $3 \%$ \\
\hline Nominal Bond Rate & $8.6 \%$ \\
\hline Federal Corporate Tax Rate & $35 \%$ \\
\hline Average State Corporate Tax Rate & $6.6 \%$ \\
\hline Combined Tax Rate & $39.3 \%$ \\
\hline Depreciation Method & MACRS \\
\hline
\end{tabular}

The nominal bond rate is based on the fifty year average of Baa bond yields as reported in the Economic Report of the President. The average state corporate tax rate is taken from Ernst \& Young (2007). Table A2 gives my assumed technology and cost assumptions for wind and natural gas projects.

\begin{tabular}{|c|c|c|}
\hline \multicolumn{3}{|c|}{ Table A2. Technology and Cost Assumptions } \\
\hline & Natural Gas & Wind \\
\hline Capacity Factor & $85 \%$ & $35 \%$ \\
\hline Construction Time & 2 & 3 \\
\hline Fuel Cost (\$/MMbtu) & 7.00 & 0 \\
\hline Heat rate (BTU/kWh) & 9,289 & na \\
\hline fuel escalation & $0.00 \%$ & $0.00 \%$ \\
\hline fixed O\&M (\$/kW/yr) & 10.53 & 30.30 \\
\hline variable O\&M (\$/kWh) & 0.00317 & 0.009 \\
\hline O\&M escalation rate & $0 \%$ & $0 \%$ \\
\hline Capital Increment $(\$ / \mathrm{kW})$ & 8 & 0 \\
\hline K Increment (yrs 30+) & 14 & 0 \\
\hline \% Debt Finance & $60 \%$ & $60 \%$ \\
\hline \% Equity Finance & $40 \%$ & $40 \%$ \\
\hline Discount Rate (nominal) & $8.33 \%$ & $8.33 \%$ \\
\hline Overnight cost $(\$ / \mathrm{kW})$ & 634 & 1,923 \\
\hline Economic Life & 40 & 20 \\
\hline MACRS Life & 15 & 5 \\
\hline
\end{tabular}

The capacity factor for wind is based on the capacity factor for new wind projects as documented in Wiser and Bolinger (2008). Other assumptions are taken from the Electricity Market Module of Energy Information Administration (2009). For a discussion of the tax treatment of energy investment, see Metcalf (2009b). 


\section{References}

Bolinger, Mark; Wiser, Ryan; Cory, Karlynn and James, Ted. 2009. "PTC, ITC, or Cash Grant?," Berkeley: Lawrence Berkeley National Laboratory LBNL-1642E.

Brealey, Richard and Myers, Steward. 1981. Principles of Corporate Finance. New York: McGraw-Hill.

Chadbourne and Parke, LLP."Trends in Tax Equity for Renewable Energy," New York, January 2009.

Davis, Lucas W. and Kahn, Matthew E. 2008. "International Trade in Used Durable Goods: The Environmental Consequences of NAFTA," Cambridge MA: National Bureau of Economic Research Working Paper No. 14565.

Elmendorf, Douglas W. 2009. "Flexibility in the Timing of Emission Reductions Under a Cap-and-Trade Program," Washington, DC: Congressional Budget Office.

Energy Information Administration. 2008. "Federal Financial Interventions and Subsidies in Energy Markets 2007," Washington, DC: EIA SR/CNEAF/2008-01. . 2009. "Annual Energy Outlook 2009," Washington, DC: U.S. Energy Information Administration DOE/EIA-0383(2009).

Environmental Protection Agency. 2009. "Inventory of U.S. Greenhouse Gas Emissions and Sinks: 1990 - 2007," Washington, DC: Environmental Protection Agency EPA 430-R-09-004.

Ernst \& Young. 2007. "International Comparison of Depreciation Rules and Tax Rates for Selected Energy Investments."

Herszenhorn, David M."House Reaches a Deal on 'Cash for Clunkers' Program," New York Times, New York, May 5, 2009.

Holland, Stephen P.; Hughes, Jonathan E. and Knittel, Christopher R. 2009. "Greenhouse Gas Reductions under Low Carbon Fuel Standards?" The American Economic Journal: Economic Policy, 1(1). 106-46.

Joint Committee on Taxation. 2009. "Tax Expenditures for Energy Production and Conservation," Washington, DC: Joint Committee on Taxation JCX-25-09.

Metcalf, Gilbert E. 2007. "Federal Tax Policy towards Energy." Tax Policy and the Economy, 21. 145-84. 
. 2008. "Using Tax Expenditures to Achieve Energy Policy Goals." American

Economic Review, 98(2). 90-94.

. 2009a. "Reacting to Greenhouse Gas Emissions: A Carbon Tax to Meet Emission Targets," Medford, MA: Tufts University Department of Economics.

. 2009b. "Taxing Energy in the United States: Which Fuels Does the Tax Code Favor?," New York: The Manhattan Institute.

Metcalf, Gilbert E. and Weisbach, David. forthcoming. "The Design of a Carbon Tax." Harvard Environmental Law Review.

Mouawad, Jad and Krauss, Clifford."Lawmakers May Limit Paper Mills' Windfall," New York Times, New York, p. B1, April 18, 2009.

Office of Management and Budget. 2009. "Budget of the United States Government, Fiscal Year 2010," Washington, DC: U.S. Government Printing Office.

Pigou, Arthur C. 1932. The Economics of Welfare. London: MacMillan and Co.

Searchinger, Timothy; Heimlich, Ralph; Houghton, R.A.; Dong, Fengxia; Elobeid, Amani; Fabiosa, Jacinto; Tokgoz, Simla; Hayes, Dermot and Yu, Tun-Hsiang. 2008. "Use of U.S. Croplands for Biofuels Increases Greenhouse Gases Through Emissions from Land-Use Change." Science, 319(5687). 1238-40.

Sullivan, Martin A. 2009. "Tech Neutrality, Tax Credits, and the Gas Tax." Tax Notes, 122(5). 619-24.

Wiser, Ryan and Bolinger, Mark. 2008. "Annual Report on Wind Power Installation, Cost, and Performance Trends: 2007," Washington, DC: U.S. Department of Energy. 